\title{
Study on the Volatile Components of 130-Year-aged "Nukadoko" for Pickling
}

\author{
Masatake ImaI, Akiyoshi Sato* and Hiroshi IshII* \\ Research Institute of Morinaga and Co., 2-1-1 Shimosueyoshi, \\ Tsurumi-ku, Yokohama 230, Japan \\ * Central Research Laboratory of Takasago International Co., \\ 5-36-31, Kamata, Ohta-ku, Tokyo 144, Japan
}

Received December 5, 1990

\begin{abstract}
The volatile compounds of aged "Nukadoko" were studied using a sample that had been aged for 130 years. The fatty acid, 10-hydroxy-octadecanoic acid, which is considered to be an aging index compound in "Nukadoko", comprised $47 \%$ of all the free fatty acids and showed that sufficient aging had been carried out. The volatile components of the "Nukadoko" obtained by freeze drying were quantitatively determined by GC and GC-MS analyses. In the result, 39 esters, 13 acids, 23 alcohols, 13 hydrocarbons, 8 phenols, 9 lactones, 2 aldehydes, 2 ketones and sulfur-nitrogen-containing compounds were found. Quantitatively, $70 \%$ of the volatile compounds consisted of acids, which were mainly propionic, butyric and acetic acids in order of magnitude. The next major components were phenethylalcohol, 3-butenyl isothiocyanate, 4-ethyl guaiacol, 2-methoxy-4-cresol, 3-ethylphenol and nona-1,4-olide. Esters, which formed the large portion of all the volatile constituents, comprised amyl formate, propyl acetate, propyl propionate, ethyl acetate, phenethyl propionate, propyl palmitate and propyl oleate. Of the sulfur-nitrogen-containing compounds, 3-methyl-thiopropanol, 3-butenyl isothiocyanate, phenethyl isothiocyanate and phenylpropiononitrile were found. Limonene, linalool and trans-nerolidol were also detected. Undecan-1,4-olide, 3-ethyl-phenol and butan-1,4-olide were evaluated as the character-impact components by sniffing.
\end{abstract}

"Nukamiso-zuke", one of the characteristic pickles found in Japan, has a complex and favorable flavor which does not exist in other Japanese pickles. Until "Nukadoko", the base for pickling, has formed a good flavor, it requires daily attention.

We have already reported the changes in microflora, ${ }^{1,2)}$ organic acids, fatty acids and flavor components ${ }^{3)}$ during the 120-day aging of "Nukadoko", and found that it took at least 60 days to develop the aged flavor. However, in that report, ${ }^{3)}$ quantitative analyses of the flavor components was not conducted, especially of the volatile compounds with lower boiling point.

Reports on the volatile components of Japanese pickles are very few, studies only having been made on the volatile constituents of "Takana-zuke", ${ }^{4)}$ volatile isothiocyanates of vegetables, "5) flavor compounds of "Shibazuke", ${ }^{6)}$ and the flavor of pickles by the head space method. ${ }^{7)}$ No report exists on a quantitative analysis of the flavor compounds of "Nukamiso-zuke" and "Nukadoko". One of the difficulties in studying these is that the flavor of "Nukadoko" varies according to the length of aging and degree of attention. Therefore, it is important in a study on the flavor of "Nukadoko" to select typical "Nukadoko" which has been sufficiently aged with good attention.

In this work, we selected 130-year-aged "Nukadoko" as the typical sample for the analyses, this being still used for daily consumption, and quantitatively analysed the volatile components of this typical sample.

\section{Materials and Methods}

130-Year-aged "Nukadoko". The "Nukadoko" was provided by Mrs. Mitsuko Yamamoto of 1-17-8, Minami Ikuta, Tama-ku, Kawasaki-shi. It was aged in an earth- 
enware pot with a wooden lid in a compartment under the floor of the kitchen.

The sample has been throughly mixed twice a day by hand and vegetables are put into it every morning and evening. The vegetables for pickling vary according to the season, cucumber and egg plant being pickled throughout the year, with turnip, radish and carrot often being pickled and cabbage rarely. When the "Nukadoko" gets too moist, 1 or $2 \mathrm{~kg}$ of fresh rice bran and about $400 \mathrm{~g}$ of salt are added about once a month, and the mixture throughly stirred. Once every two months, 2 pieces of tangle of $50 \mathrm{~cm}$ length are put into it.

This "Nukadoko" has been passed from mother to daughter since the 2nd year of the Kohka era, 1845, in this family and has been carefully attended to every day. During the winter seasons, this "Nukadoko" has not been used, its surface being covered with a thick layer of salt to avoid microbial growth. This salt layer is removed every spring.

Sample of the 130-year-aged "Nukadoko" for analysis. The state of the "Nukadoko" in this sample was just before adding new rice bran and salt. About $3 \mathrm{~kg}$ of the "Nukadoko" was packed into a plastic bag made from KON\#15/DL/aluminum vacuum metalized-LLDPE 30. After being taken to the laboratory, the sample was immediately divided into about $300 \mathrm{~g}$ portions in $500 \mathrm{ml}$ Erlenmeyer flasks. The flasks were sealed in nitrogen and stored in a freezer at $-25^{\circ} \mathrm{C}$ untill required for analysis. Thawing was done at room temperature.

Collection of the volatile compounds. $600 \mathrm{ml}$ of deionized water was added to $411 \mathrm{~g}$ of "Nukadoko" in a homogenizer to form a suspension. This suspension was divided into four portions, each being placed into a 1-1 rounded bottom flask. The flasks were rotated in an acetone/dry ice bath $\left(-80^{\circ} \mathrm{C}\right)$ and connected to lyophylization apparatus.

Lyophylization $^{8-10)}$ was carried out for $8 \mathrm{hr}$ under a pressure of $0.5 \mathrm{mmHg}$. The distillates in the first and second traps were combined after thawing at ambient temperature, and the obtained distillate $(800 \mathrm{ml})$ was extracted with $900 \mathrm{ml}$ of a mixture of $n$-pentane-methylenedichloride $(2: 1)$. The organic layer including the volatile aroma compounds was set aside, and the aqueous layer was divided into four portions. One portion was added to each of the four flasks containing the lyophylized residue and homogenized with a magnetic stirrer for ten minutes. After standing in a refrigerator at $3^{\circ} \mathrm{C}$ overnight, lyophylization was carried out again by the same procedure.

This complete lyophylization method was repeated once, and the volatiles were extracted with 1.91 of the same solvent.

Approximately 3.31 of extract obtained from $411 \mathrm{~g}$ of "Nukadoko" was dried over anhydrous sodium sulfate overnight and concentrated to $0.1 \mathrm{ml}$ in Kuderna Danish concentrate apparatus at $45^{\circ} \mathrm{C}$. The remaining solvent was throughly removed under a stream of nitrogen.
The yield of the aroma concentrate was $40 \mathrm{mg}$, the concentration to "Nukadoko" being $97.3 \mathrm{ppm}$ ("Nukadoko 1").

Preparation of an acid-free aroma concentrate. Since the gas chromatogram of "Nukadoko 1" showed that aliphatic acids comprised $70 \%$ of the total volatiles, $30 \mathrm{mg}$ of "Nukadoko 1" dissolved in $10 \mathrm{ml}$ of diethylether were shaken vigorously with $2 \mathrm{ml}$ of a $10 \%$ aqueous $\mathrm{NaHCO}_{3}$ solution to eliminate the acids. This extraction was repeated twice with $10 \mathrm{ml}$ each of diethylether, before the combined extracts were washed with $2 \mathrm{ml}$ of water saturated with sodium chloride. After drying over anhydrous sodium sulfate, diethylether was removed with the Kuderna Danish apparatus.

The yield of the acid-free aroma concentrate was $10 \mathrm{mg}$ ("Nukadoko 2") at a concentration of $32.4 \mathrm{ppm}$.

Gas chromatography and gas chromatography-mass spectrometry. The flavor components were analyzed by gas chromatography with Perkin-Elmer model 8420-GC apparatus equipped with a flame ionization detector and PEG $20 \mathrm{M}$ fused silica capillary column $(25 \mathrm{~m} \times 0.20 \mathrm{~mm}$ i.d.), and then identified by GC/MS with a Hitachi $80-B$ mass spectrometer connected to an HP-5790 gas chromatograph, which was equipped with the same capillary column. The temperature of the $\mathrm{GC}$ injector was $220^{\circ} \mathrm{C}$, the column being held initially at $70^{\circ} \mathrm{C}$ for $4 \mathrm{~min}$, and then programmed at $4^{\circ} \mathrm{C} / \mathrm{min}$ to $220^{\circ} \mathrm{C}$. Data were acquired and analyzed by a Hitachi data processing system.

\section{Results and Discussion}

\section{General constituents}

The aged flavor of "Nukadoko" is complex and has been formed by many factors. One of the purposes of this report is to elucidate the volatile compounds of typical "Nukadoko", and the other is to speculate on the pathway for producing the volatiles. The general constituents, free amino acids, organic acids and free fatty acids, were analyzed for the latter purpose and compared with freshly prepared "Nukadoko", which was formed from $200 \mathrm{~g}$ of fresh rice bran, $30 \mathrm{~g}$ of salt and $346 \mathrm{ml}$ of water. The results are shown in Tables I, II, III and in Fig. 1.

The general constituents which directly affect the aged flavor are sugars and salt, whose concentration controls the acid production by lactic acid bacteria. As a result, the $\mathrm{pH}$ of "Nukadoko" has a great influence on the volatile compounds through the microflora. As 
Table I. General Constituents (\%) in 130-Year "Nukadoko" and in Freshly Prepared

\begin{tabular}{|c|c|c|c|c|c|c|c|c|c|c|}
\hline & Moisture & Fat & $\begin{array}{l}\text { Reducing } \\
\text { sugar }\end{array}$ & Sucrose & Protein & Ash & $\mathrm{NaCl}$ & $\begin{array}{l}\text { Acid as } \\
\text { lactic }\end{array}$ & $\mathrm{pH}$ & $\begin{array}{c}\mathrm{VB}_{1} \\
(\mathrm{mg} \%)\end{array}$ \\
\hline $\begin{array}{l}130 \text { Years } \\
\text { "Nukadoko" }\end{array}$ & $\begin{array}{c}74.6 \\
(70.0)^{a}\end{array}$ & $\begin{array}{c}7.2 \\
(7.6)\end{array}$ & $\begin{array}{c}0.01 \\
(0.01)\end{array}$ & $\begin{array}{c}0.1 \\
(0.11)\end{array}$ & $\begin{array}{c}3.20 \\
(3.39)\end{array}$ & $\begin{array}{c}3.81 \\
(4.03)\end{array}$ & $\begin{array}{c}2.30 \\
(2.44)\end{array}$ & $\begin{array}{c}2.48 \\
(2.62)\end{array}$ & 4.43 & $\begin{array}{c}0.208 \\
(0.221)\end{array}$ \\
\hline $\begin{array}{l}\text { Freshly prepared } \\
\text { "Nukadoko" }\end{array}$ & 70.0 & 6.50 & 2.05 & 0.27 & 4.18 & 6.51 & 5.05 & 1.29 & 5.96 & 2.70 \\
\hline
\end{tabular}

( $)^{a}$ : Values converted into the same moisture \% as that of freshly prepared "Nukadoko".

Table II. Free Amino Acids (\%) in 130-Year-aged "Nukadoko" and in Freshly Prepared "NukAdoko", AND the AMINo ACID COMPOSITION ( $\mathrm{g} / 16.8 \mathrm{~g}$ of $\mathrm{N}$ ) OF RicE BRAN

\begin{tabular}{|c|c|c|c|c|c|c|c|}
\hline Amino acid & 130 years & New & Rice (II) bran & Amino acid & 130 Years & New & Rice bran \\
\hline Asp & 9 & 22 & 10.0 & Ileu & 35 & 2 & 3.6 \\
\hline Thr & 25 & 7 & 4.2 & Leu & 59 & 4 & 7.6 \\
\hline Ser & 28 & 6 & 5.3 & Tyr & $\operatorname{Tr}$ & 4 & 3.4 \\
\hline Glu & 39 & 10 & 14.1 & Phe & 18 & 2 & 4.8 \\
\hline Pro & 24 & 4 & 5.1 & His & 15 & 5 & 3.1 \\
\hline Gly & 45 & 4 & 5.7 & Lys & 1 & 5 & 5.3 \\
\hline Ala & 153 & 14 & 6.4 & Arg & $\operatorname{Tr}$ & 14 & 8.4 \\
\hline Cys & 34 & $\mathrm{Tr}$ & 2.5 & Val & 54 & 5 & 5.7 \\
\hline Met & 12 & 2 & 2.1 & Trp & - & - & 0.9 \\
\hline \multirow[t]{2}{*}{$\gamma$-aba } & 73 & 27 & - & $\left(\mathrm{NH}_{3}\right)$ & 21 & 2 & 4.5 \\
\hline & & & & Total & 624 & 137 & \\
\hline
\end{tabular}

Analysis by HPLC, after extracting for $20 \mathrm{~min}$. at $40^{\circ} \mathrm{C}$ by a sonicator. Deproteinization by $60 \%$ EtOH. AA-PAK column $(6 \mathrm{~mm} \times 140 \mathrm{~mm})$, Nippon Bunko; column temp., $63^{\circ} \mathrm{C}$; eluent, sodium citrate buffer (pH $3.06, \mathrm{pH} 4.25$ and $\mathrm{pH} 10.50 \mathrm{stepwise})$; flow rate, $0.6 \mathrm{ml} / \mathrm{min}$; detection, proline at $440 \mathrm{~nm}$, and others at $570 \mathrm{~nm}$.

shown in Table I, the fermentable sugars had almost all been consumed in the 130-year "Nukadoko". Consequently, the microorganisms are considered to utilize the fermentable sugars that are exuded from the vegetables by osmotic pressure, as well as the free amino acids and organic acids in "Nukadoko" as carbon sources. As shown in Tables II and III, $\gamma$-amino butyric acid, $\alpha$-ketoglutaric acid and (NH3) were the resulting compounds of the decarboxylation ${ }^{14)}$ and deamination ${ }^{14)}$ of glutamic acid and other amino acids. Many species of the lactic acid bacteria ${ }^{1)}$ found in "Nukadoko" have the ability to assimilate amino acids. ${ }^{16)}$ Free amino acids are important, not only as a nutrient for microorganisms, but as sources $^{12,13)}$ of the volatile components of higher alcohols, carbonyl compounds, fatty acids and others, which are mainly converted by yeasts.

Table III shows a comparison of the organic acids. The malic, malonic and citric acids contained in the new "Nukadoko" were not detected in the aged "Nukadoko". It is speculated that these organic acids were converted to acetic and lactic acid by Pediococcus halophilus ${ }^{18,22)}$ and also seem to have affected the flavor compounds. Great care is needed to maintain low $\mathrm{pH}$ value of "Nukadoko", and as a result, this seems to prevent the increase of undesirable flavors like amines by putrefactive bacteria.

Figure 1 shows the difference of free fatty acids between the 130-year "Nukadoko" and the newly prepared type. Imai ${ }^{3)}$ has already reported that fatty acids, ODAX (octadecanoic acid-10,13-oxide) and HODA (10-hydroxy octadecanoic acid), apparently increased as 
Table III. ORganic ACIDS IN 130-YEAR-AGED "NukADOKO" AND IN FRESHLy PREPAREd "NuKadoKo" (mg\%)

\begin{tabular}{lcc}
\hline \multicolumn{1}{c}{ Acid } & 130years & New \\
\hline Formic & Tr & - \\
Acetic & 337 & - \\
Propionic & 143 & - \\
Lactic & 802 & - \\
Malic & - & 17 \\
Malonic & - & 64 \\
Citric & - & - \\
Succinic & 28 & 105 \\
$\alpha$-Keto-glutaric & 201 & - \\
Pyro glutamic & 19 & 4805 \\
Oxalic & 2503 & 5011 \\
\hline Total & 4033 & \\
\hline
\end{tabular}

a The quantity of oxalic acid is not accurate because the position of this peak was obscured by sodium chloride.

Analysis by HPLC, after extracting for $20 \mathrm{~min}$ at $40^{\circ} \mathrm{C}$ by a sonicator. Deproteinization by $80 \%$ EtOH. HC-125S column $(6 \mathrm{~mm} \times 140 \mathrm{~mm})$, Showa Denko Co; column temp., $61.5^{\circ} \mathrm{C}$; eluent, $\mathrm{HClO}_{4}$ soln. $(0.003 \mathrm{M})$; flow rate, $0.6 \mathrm{ml} / \mathrm{min}$; reagent, BTB soln.; detection, $440 \mathrm{~nm}$. aging proceeded, and proposed to use these as the aging index compounds of "Nukadoko". These compounds, especially HODA, were also present in the 130-year "Nukadoko" and are presumed to have been formed from $\mathrm{C} 18: 1$ and C18:2 fatty acids. As a result, the free fatty acid, 10-hydroxy octadecanoic acid, which is considered to be an aging index compound, comprised $47 \%$ of all the free fatty acids, indicating that sufficient aging had occurred.

\section{Volatile compounds in the 130-year "Nukado- ko"}

Figure 2 shows gas chromatogram of the volatiles in "Nukadoko 1", which comprised $70 \%$ acids, including the lower fatty acids. Therefore, to identify the minor volatile constituents, these acids were eliminated from the volatile fraction of "Nukadoko 1" as already mentioned. The gas chromatogram of the acid-free portion (10 $\mathrm{mg}$ ) as "Nukadoko 2" is shown in Fig. 3.

Finally, 115 constituents were identified by

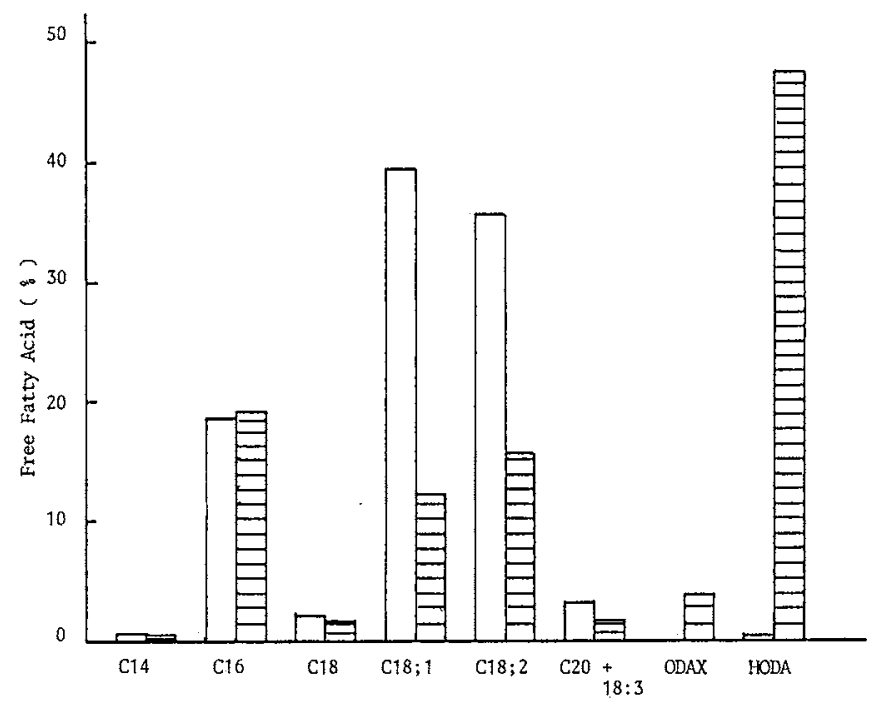

Fig. 1. Ratio of Fatty Acids to Total Free Fatty Acids in 130-Year "Nukadoko" and Freshly Prepared "Nukadoko".

$\boxminus$, 130-year "Nukadoko"; $\square$, freshly prepared "Nukadoko"; ODAX, octadecanoic acid-10,13-oxide; HODA, 10-hydroxy octadecanoic acid.

$5.0 \mathrm{~g}$ of the sample was extracted 3 times by ethylether. The concentrate was eluted by benzene and ethylether from a silica gel column. The ether fraction was concentrated and methyl-esterified by the boron trifluoride-methanol method. GC column, sp-2330 ( $3 \mathrm{~m} \times 4.0 \mathrm{~mm})$ Nihon Gasukuro Kogyo Co.; column temp., $80-250^{\circ} \mathrm{C} / \mathrm{min}$; gas, $\mathrm{N}_{2}$; flow rate, $30 \mathrm{ml} / \mathrm{min}$; detector, FID. 
Nukadoko 1

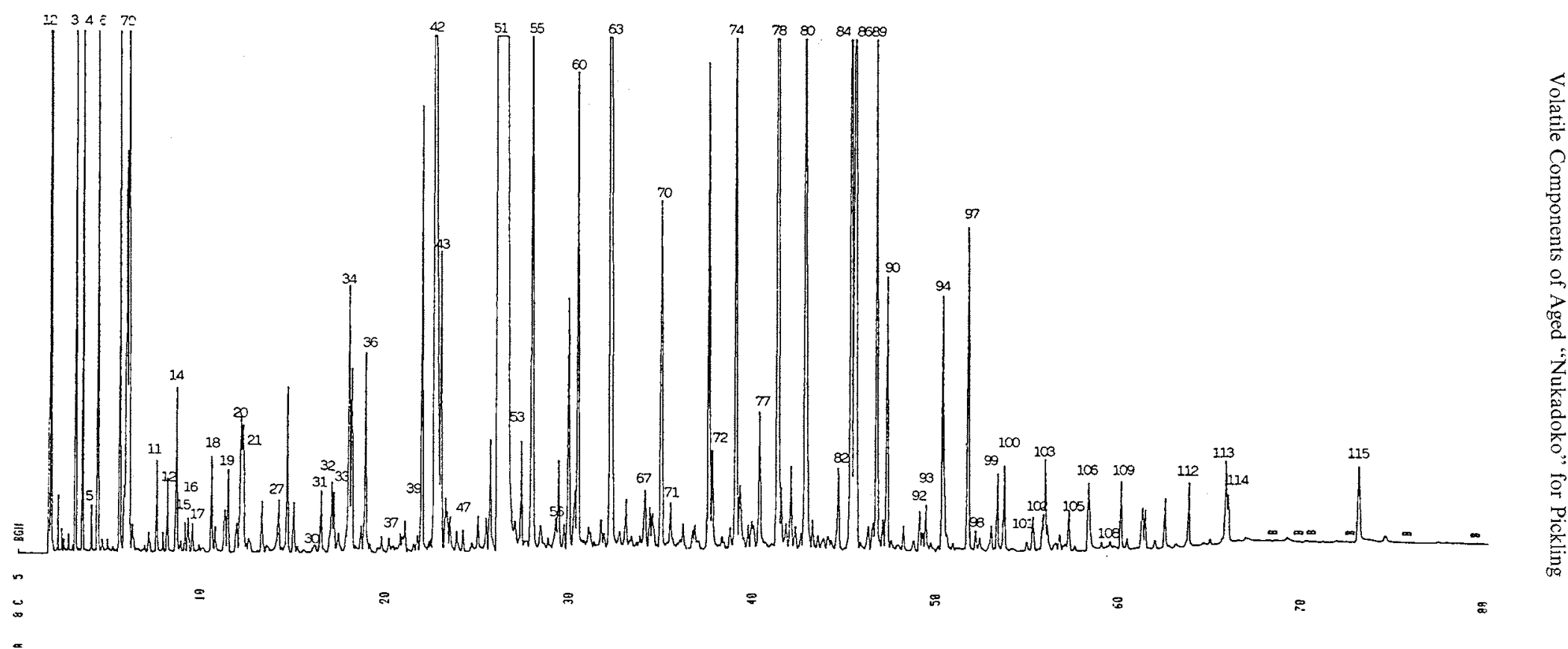

Fig. 2. Gas Chromatogram of the Volatile Components of "Nukadoko 1". 
Nukadoko 2

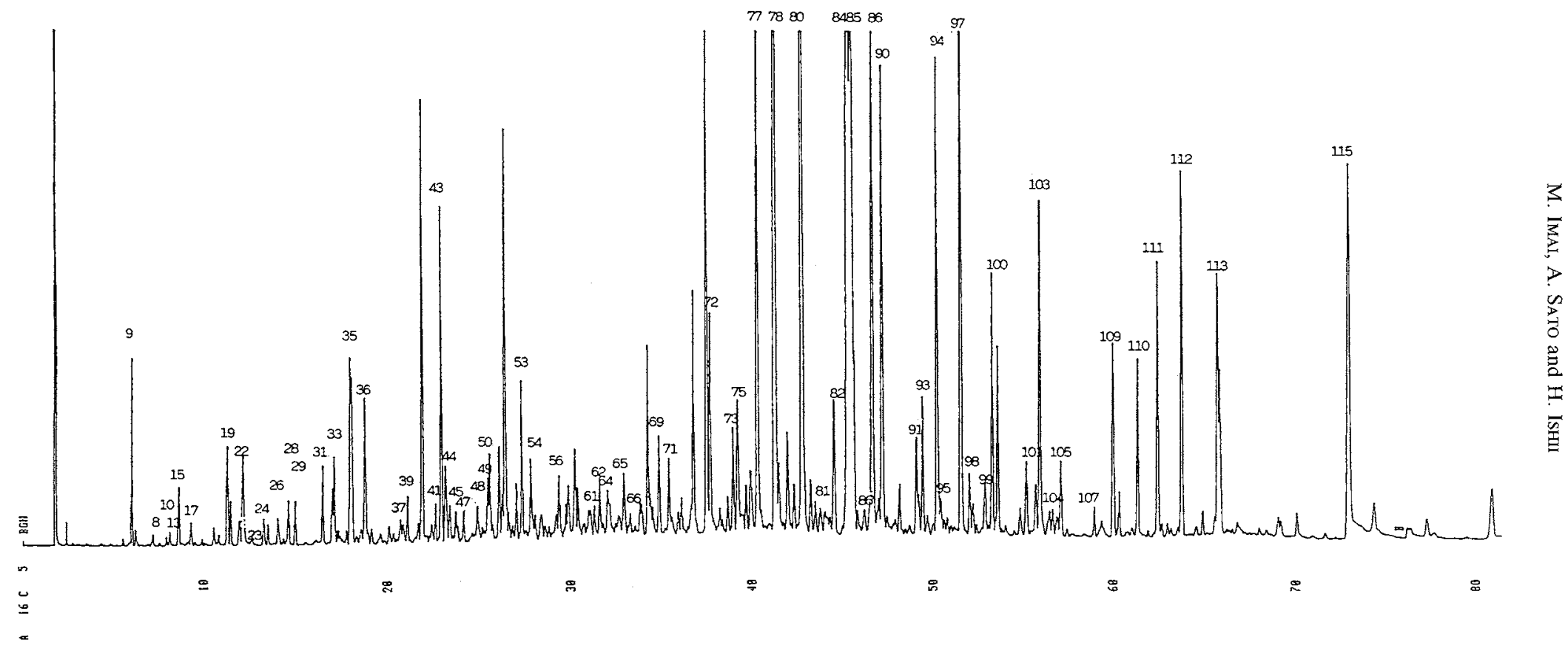

Fig. 3. Gas Chromatogram of the Volatole Components of "Nukadoko 2". 
GC and GC-MS an alyses of "Nukadoko 1" and "Nukadoko 2". They were classed on the basis of their functional groups, and are shown in Table IV with their percentage amount. The constituents comprised 39 esters, 13 acids, 23 alcohols, 13 hydrocarbons, 8 phenols, 9 lactones, 2 aldehydes and ketones, and sulfurnitrogen-containing compounds.
From these results, the flavor of aged "Nukadoko" seems to be formed by a complex of various acids, esters, aliphatic alcohols, phenols, nitrile/isothiocyanates, lactones and phenethyl alcohol.

It seems that the production of aroma components in aged "Nukadoko" is greatly affected by microbial activity in the same way

Table IV. Percentage Area of Flavor Components from "Nukadoko I" and "Nukadoko 2"

\begin{tabular}{|c|c|c|c|c|}
\hline & \multicolumn{2}{|c|}{ Peak no. } & $\begin{array}{c}\text { "Nukadoko l" } \\
97.3 \mathrm{mg} / \mathrm{kg}(\mathrm{ppm}) \\
\text { Area \% (ppb) }\end{array}$ & $\begin{array}{c}\text { "Nukadoko 2" } \\
32.4 \mathrm{mg} / \mathrm{kg}(\mathrm{ppm}) \\
\text { Area } \%(\mathrm{ppb})\end{array}$ \\
\hline \multirow[t]{40}{*}{ Esters } & 2 & Amyl formate & $0.570(554.6)$ & - \\
\hline & 5 & Ethyl propionate & $0.071(69.1)$ & - \\
\hline & 6 & Propyl acetate & $1.082(1052.8)$ & - \\
\hline & 8 & Isobutyl propionate & - & $0.036(11.7)$ \\
\hline & 9 & Propyl propionate & $1.984(1930.4)$ & $0.367(\mathrm{I} 18.9)$ \\
\hline & 15 & Propyl butyrate & $0.055(53.5)$ & $0.174(56.4)$ \\
\hline & 17 & Propyl 2-methylbutyrate & $0.071(69.1)$ & $0.063(20.4)$ \\
\hline & 19 & 2-Methylbutyl propionate & $0.159(154.7)$ & $0.390(126.4)$ \\
\hline & 23 & Propyl valerate & - & $0.058(18.8)$ \\
\hline & 24 & Ethyl caproate & - & $0.116(38.2)$ \\
\hline & 25 & Amyl propionate & - & $0.083(26.9)$ \\
\hline & 28 & Hexyl acetate & - & $0.180(58.3)$ \\
\hline & 30 & cis-3-Hexenyl acetate & $0.057(55.5)$ & - \\
\hline & 32 & Propyl caproate & $0.194(188.8)$ & $0.177(57.3)$ \\
\hline & 34 & Ethyl lactate & $0.496(482.6)$ & - \\
\hline & 35 & Hexyl propionate & - & $0.592(191.8)$ \\
\hline & 40 & Ethyl caprylate & - & $0.111(36.0)$ \\
\hline & 41 & Heptyl propionate & - & $0.136(44.1)$ \\
\hline & 46 & Octyl acetate & - & $0.127(41.1)$ \\
\hline & 50 & Propyl caprylate & - & $0.330(106.9)$ \\
\hline & 52 & Octyl propionate & - & $0.242(78.4)$ \\
\hline & 61 & 1,3-Propanediol diacetate & - & $0.282(91.4)$ \\
\hline & 69 & 1,3-Propanediol monoacetate & - & $0.483(156.5)$ \\
\hline & 71 & Propyl benzoate & $0.123(119.7)$ & $0.345(111.8)$ \\
\hline & 72 & Phenethyl acetate & $0.242(235.5)$ & $0.814(263.7)$ \\
\hline & 76 & Propyl phenyl acetate & - & $0.257(83.3)$ \\
\hline & 77 & Phenethyl propionate & $0.423(411.6)$ & $2.451(794.1)$ \\
\hline & 83 & Methyl myristate & - & $0.111(36.0)$ \\
\hline & 86 & Ethyl myristate & 一 & $0.231(74.8)$ \\
\hline & 93 & Propyl myristate & $0.106(103.1)$ & $0.535(173.3)$ \\
\hline & 98 & Methyl palmitate & $0.046(44.8)$ & $0.260(84.2)$ \\
\hline & 100 & Ethyl palmitate & $0.209(203.4)$ & $0.884(286.4)$ \\
\hline & 103 & Propyl palmitate & $0.270(165.4)$ & $1.436(465.3)$ \\
\hline & 107 & Methyl oleate & - & $0.150(48.6)$ \\
\hline & 109 & Ethyl oleate & $0.148(144.0)$ & $0.872(282.5)$ \\
\hline & 110 & Ethyl linoleate & - & $0.680(220.3)$ \\
\hline & 111 & Propyl oleate & - & $1.036(335.7)$ \\
\hline & 112 & Propyl linoleate & $0.160(156.7)$ & $1.304(422.5)$ \\
\hline & 113 & Dibutyl phthalate & $0.180(175.1)$ & $1.054(341.5)$ \\
\hline & & Total & 6.546 & 15.867 \\
\hline
\end{tabular}


Table IV. (Continued)

\begin{tabular}{|c|c|c|c|c|}
\hline & Peak no. & & $\begin{array}{c}\text { "Nukadoko 1" } \\
97.3 \mathrm{mg} / \mathrm{kg}(\mathrm{ppm}) \\
\text { Area \% (ppb) }\end{array}$ & $\begin{array}{c}\text { "Nukadoko 2" } \\
32.4 \mathrm{mg} / \mathrm{kg}(\mathrm{ppm}) \\
\text { Area \% (ppb) }\end{array}$ \\
\hline \multirow[t]{14}{*}{ Acids } & 42 & Acetic acid & $3.219(3132.1)$ & - \\
\hline & 51 & Propionic acid & $54.476(53005.2)$ & - \\
\hline & 55 & Isobutyric acid & $1.604(1560.7)$ & - \\
\hline & 60 & Butyric acid & $1.066(1037.2)$ & - \\
\hline & 63 & 2-Methylbutyric acid & $4.877(4745.3)$ & - \\
\hline & 70 & Valeric acid & $0.987(960.4)$ & - \\
\hline & 74 & Caproic acid & $1.772(1724.2)$ & - \\
\hline & 89 & Caprylic acid & $1.109(1079.1)$ & - \\
\hline & 94 & Nonanoic acid & $0.627(610.1)$ & - \\
\hline & 106 & Benzoic acid & $0.242(235.5)$ & - \\
\hline & 108 & Lauric acid & $0.026(25.3)$ & - \\
\hline & 114 & Myristic acid & $0.120(116.8)$ & - \\
\hline & 115 & Palmitic acid & $0.302(293.9)$ & $2.412(781.5)$ \\
\hline & & Total & 70.427 & 2.412 \\
\hline \multirow[t]{3}{*}{ Aldehydes } & 33 & trans-2-Heptenal & $0.130(126.5)$ & $0.266(86.2)$ \\
\hline & 49 & Benzaldehyde & - & $0.217(70.3)$ \\
\hline & & Total & 0.130 & 0.483 \\
\hline \multirow[t]{3}{*}{ Ketones } & 3 & 2-Butanone & $1.405(1367.1)$ & - \\
\hline & 91 & 6,10,14-Trimethylpentadecan-2-one & - & $0.447(114.8)$ \\
\hline & & Total & 1.405 & 0.447 \\
\hline \multirow[t]{14}{*}{ Hydrocarbons } & 10 & Decane & - & $0.027(8.7)$ \\
\hline & 21 & Limonene & $0.333(324.0)$ & $0.126(40.8)$ \\
\hline & 26 & Isobutylbenzene & - & $0.143(46.3)$ \\
\hline & 29 & Trimethylbenzene & - & $0.152(49.2)$ \\
\hline & 31 & Tridecane & $0.163(158.6)$ & $0.263(85.2)$ \\
\hline & 39 & Tetradecane & $0.048(\quad 46.7)$ & $0.177(57.3)$ \\
\hline & 48 & Pentadecane & - & $0.277(89.7)$ \\
\hline & 57 & Hexadecane & - & $0.322(104.3)$ \\
\hline & 64 & Ethylbenzene & - & $0.253(82.0)$ \\
\hline & 66 & Heptadecane & - & $0.198(64.2)$ \\
\hline & 68 & Naphthalene & - & $0.224(72.6)$ \\
\hline & 73 & 2-Methylnaphthalene & - & $0.503(163.0)$ \\
\hline & 81 & 2,6-Dimethylnaphthalene & - & $0.182(59.0)$ \\
\hline & & Total & 0.544 & 2.847 \\
\hline \multirow{6}{*}{$\begin{array}{l}\text { S,N- } \\
\quad \text { compounds }\end{array}$} & 43 & 3-Butenyl isothiocyanate & $0.545(530.3)$ & $0.998(323.4)$ \\
\hline & 67 & 3-Methylthiopropanol & $0.216(210.2)$ & - \\
\hline & 87 & Phenylpropionitrile & $2.422(2356.6)$ & $2.687(870.6)$ \\
\hline & 97 & Phenethyl isothiocyanate & $0.748(727.8)$ & $2.553(827.2)$ \\
\hline & & Total & 3.931 & 6.218 \\
\hline & & Weight & $97.3 \mathrm{mg} / \mathrm{kg}(\mathrm{ppm})$ & $32.4 \mathrm{mg} / \mathrm{kg}(\mathrm{ppm})$ \\
\hline
\end{tabular}


Table IV. (Continued)

\begin{tabular}{|c|c|c|c|c|}
\hline & Peak no & & $\begin{array}{c}\text { "Nukadoko 1" } \\
97.3 \mathrm{mg} / \mathrm{kg}(\mathrm{ppm}) \\
\text { Area \% (ppb) }\end{array}$ & $\begin{array}{c}\text { "Nukadoko 2" } \\
32.4 \mathrm{mg} / \mathrm{kg}(\mathrm{ppm}) \\
\text { Area \% (ppb) }\end{array}$ \\
\hline \multirow[t]{24}{*}{ Alcohols } & 7 & Isopropanol & $0.874(850.4)$ & - \\
\hline & 11 & Isobutanol & $0.174(169.3)$ & - \\
\hline & 12 & 3-Pentanol & $0.144(140.1)$ & 一 \\
\hline & 13 & 2-Pentanol & - & $0.063(20.4)$ \\
\hline & 14 & 3-Methylbutan-2-ol & $0.330(321.1)$ & - \\
\hline & 16 & Butanol & $0.078(75.9)$ & - \\
\hline & 18 & 3-Methyl-3-buten-2-ol & $0.338(37.0)$ & - \\
\hline & 20 & 2-Methylbutanol & $0.309(300.7)$ & - \\
\hline & 22 & Isoamyl alcohol & - & $0.408(132.2)$ \\
\hline & 27 & Amyl alcohol & $0.167(162.5)$ & 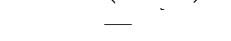 \\
\hline & 36 & Hexanol & $0.404(393.1)$ & $0.567(183.7)$ \\
\hline & 37 & 3-Ethoxy propanol & $0.054(51.6)$ & - \\
\hline & 38 & Octan-3-ol & - & $0.130(42.1)$ \\
\hline & 44 & 1-Octen-3-ol & - & $0.362(117.3)$ \\
\hline & 45 & 6-Methyl-5-hepten-3-ol & - & $0.187(60.6)$ \\
\hline & 47 & 2-Ethylhexanol & $0.075(73.0)$ & $0.144(46.7)$ \\
\hline & 53 & Linalool & $0.247(240.3)$ & $0.495(160.4)$ \\
\hline & 54 & Octanol & - & $0.412(133.5)$ \\
\hline & 58 & trans-2-Octenol & - & $0.148(48.0)$ \\
\hline & 62 & Nonanol & - & $0.283(91.7)$ \\
\hline & 75 & 1-(2-Tetrahydrofuryl)hexanol & - & $0.641(207.7)$ \\
\hline & 78 & Phenethyl alcohol & $3.059(2976.4)$ & $7.392(2395.0)$ \\
\hline & 88 & trans-Nerolidol & $0.087(84.7)$ & - \\
\hline & & Total & 6.04 & 11.232 \\
\hline \multirow[t]{10}{*}{ Lactones } & 56 & Pentan-1,4-olide & $0.024(23.4)$ & - \\
\hline & 59 & Butan-1,4-olide & $0.187(182.0)$ & - \\
\hline & 65 & Hexan-1,4-olide & - & $0.388(125.7)$ \\
\hline & 84 & Nonan-1,4-olide & $1.681(1635.6)$ & $6.724(2178.6)$ \\
\hline & 92 & Decan-1,4-olide & $0.085(82.7)$ & - \\
\hline & 96 & 2,3-Dimethyl-2-nonen-1,4-olide & + & $0.200(64.8)$ \\
\hline & 99 & Undecan-1,4-olide & $0.168(163.5)$ & $0.308(99.8)$ \\
\hline & 101 & Dihydroactinidiolide & $0.032(31.1)$ & $0.414(134.1)$ \\
\hline & 104 & Dodecan-1,4-olide & - & $0.140(45.4)$ \\
\hline & & Total & 2.177 & 8.169 \\
\hline \multirow[t]{9}{*}{ Phenols } & 79 & $\mathrm{BHT}$ & $0.136(132.3)$ & - \\
\hline & 80 & 2-Methoxy-4-cresol & $2.727(2653.4)$ & $7.120(2306.9)$ \\
\hline & 82 & Phenol & $0.249(242.3)$ & $0.746(241.7)$ \\
\hline & 85 & 4-Ethylguaiacol & - & $5.473(1773.3)$ \\
\hline & 90 & 4-Cresol & $0.617(600.3)$ & $1.858(602.0)$ \\
\hline & 95 & 3-Ethylphenol & - & $1.933(626.3)$ \\
\hline & 102 & 2,6-Dimethoxy-4-cresol & $0.100(97.3)$ & - \\
\hline & 105 & $p$-Methoxyphenol & $0.096(93.4)$ & $0.353(114.4)$ \\
\hline & & Total & 3.925 & 17.483 \\
\hline
\end{tabular}

as other fermented foods such as soy sauce, the aging flavor of 130-year "Nukadoko" "miso", cheese and alcoholic beverages. An would be to compare with the pathways for important clue for studying the pathway for other fermented foods, and to identify their 
specificity.

A sensory evaluation of the volatile compounds of "Nukadoko 1" showed the flavor and aroma of "Nukamiso-zuke", in which the content of acids was dominant as shown Table IV. It was found that propionic acid predominated over acetic and butyric acids as the volatile components. It has been reported ${ }^{3)}$ that there was a relationship between the aging of "Nukadoko" and the production of propionic acid, but it should be noted that such large rate of propionic acid production was detected in this sample. It may be necessary to study further the production of propionic acid in "Nukadoko".

\section{Alcohols, esters and acids}

From Table IV, the existence of many kinds of acids, alcohols and esters indicates the lively microbial activity in "Nukadoko" that has been aged and used with good care. Phenethyl alcohol with a floral flavor comprised $47 \%$ of the 23 alcohols detected in "Nukadoko 1", and $66 \%$ of those in "Nukadoko 2". Ethanol was not detected, and this seems to be related to the absence of fermentable sugars in "Nukadoko" as can be seen in Table I.

Esters were the major components of the volatile compounds, and they seem to give the characteristically complex flavor to "Nukamiso-zuke". Table IV shows that esters and alcohols comprised $75 \%$ of the lower boiling point components up to peak no. 50. This means that the best flavor of "Nukamiso-zuke" would be considerably affected by esters and alcohols. The amounts of esters in "Nukadoko 1 " were $8.7 \%$ amyl formate, $16.5 \%$ propyl acetate, $30.3 \%$ propyl propionate and $7.57 \%$ ethyl lactate. The sum of these four components was $63.1 \%$. On the other hand, the amounts in "Nukadoko 2" were $14.6 \%$ phenethyl propionate, $8.8 \%$ propyl palmitate and $6.4 \%$ propyl oleate, the sum of these three compounds being $44 \%$. Judging from their relatively higher boiling point, these esters seem to influence more the taste than the aroma.

It is well known that Swiss cheese ${ }^{17)}$ contains propionic acid and also that propionibacteria produce this acid by the fermentation of lactose and lactic acid as the carbon source. However, these bacteria have not been confirmed in "Nukadoko"," although the presence of propionibacteria was anticipated. Consequently, the lower fatty acids such as propionic and butyric acids which were produced during the aging of "Nukadoko" are considered to have originated from amino acids ${ }^{12,13)}$ in the same way as with other fermented foods. Table II shows that the ratio of free glutamic acid in 130-year "Nukadoko" was lower in comparison with that in rice bran ${ }^{11}$ and in the freshly prepared "Nukadoko". Our experience shows that the characteristic flavor of aged "Nukadoko" was not produced in a pure culture of only lactic acid bacteria in the medium of rice bran, so that yeasts seem to have an important role in producing the flavor of aged "Nukadoko". In particular, conversion to fatty acids, higher alcohols and many kinds of esters from amino acids are considered to be attributable to yeasts.

The production of esters in "Nukadoko" is thought to have been carried out by almost the same mechanism as that in other fermented foods that are catalyzed by the enzyme ${ }^{20)}$ in yeast. Although a fairly large amount of ethyl acetate was detected as shown in Table IV, the fact that we could not detect the stimulative flavor of ethyl acetate at all indicates that the many flavor components in the 130-year "Nukadoko" were well balanced. Stirring the "Nukadoko" every day is considered to have had some effect on accelerating esterification. This is similar to the result by Gatfield ${ }^{22)}$ that esterification using fatty acid, alcohol and Mucor enzyme proceeded rapidly while being stirred.

\section{Sulfur-containing compounds}

The number of sulfur-containing compounds in this analysis was less than that reported in the previous paper, ${ }^{3)}$ the amounts being as shown in Table IV. Kjaer et al. ${ }^{23)}$ found such sulfur-containing compounds as 4-methyl pentyl isothiocyanate, dimethyldisulfide and methanethiol sulfinate in the volatiles from fresh radish, while Buttery ${ }^{24)}$ and 
Bailey et al. $^{25)}$ reported the presence of allyl and 4-methylthiobutyl isothiocyanates in cabbage. The sulfur-containing compounds in "Nukadoko" are considered to have been those mainly brought from such vegetables as radish, turnip and cabbage. However, they seem to have been converted to other sulfur-containing derivatives by the microorganisms in "Nukadoko" or by enzymes ${ }^{26)}$ in the vegetables, because the compounds in Table IV have not been reported in the papers just cited as sulfur-containing compounds in fresh vegetables.

\section{Phenolic compounds}

Phenolic compounds also influenced the aged flavor of "Nukadoko", 4-ethyl guaiacol, 4-cresol, 3-ethylphenol and other phenolic compounds being detected in relatively large amounts. Fujimaki et al. ${ }^{19)}$ reported the presence of guaiacol, phenol, $o$-cresol and $p$-cresol in steam distillates of rice bran. Therefore, the phenolic compounds from rice bran could be responsible for the "Nukadoko" flavor.

By a sniffing evaluation, 3-ethyl-phenol seemed definitely to be one of the characterimpact compounds. Phenolic compounds have been found in many fermented foods, especially 4-ethyl guaiacol, which characterizes the flavor of soy sauce, is well known for being produced by Torulopsis etchellsii and $T$. versatilis. ${ }^{21)} T$. etchellsii has been detected in "Nukadoko". 2)

\section{Lactones}

Lactones were reported to be key compounds ${ }^{3)}$ in aged "Nukadoko". In this current experiment, several kinds of lactones were detected in some quantity in the 130-year "Nukadoko", of which nona-1,4-olide comprised $82 \%$ of all the lactones detected.

As nona-1,4-olide has a coconut-like aroma, it is not responsible for the character-impact component. However, by our sensory evaluation, undecan-1,4-olide seemed to take a part in the characteristic flavor of aged "Nukadoko".

Okui ${ }^{15)}$ has stated that various strains of
Candida could convert ricinoleic acid into $\gamma$-decalactone.

Lactones give the sweet and pleasant flavor ${ }^{27)}$ to pickles from "Nukadoko", and a precursor of some lactones in the 130-year "Nukadoko" is considered to be HODA (10-hydroxy octadecanoic acid) as shown Fig. 1.

\section{Hydrocarbons}

The hydrocarbons seem to have originated from rice oil. Although these compounds did not directly influence the characteristic "Nukadoko" flavor, they are considered to have had a kind of penetrating action on hydrophobic components of the wax layer on the surface of vegetables, originating from the rice oil included in rice bran. These oily components also seem to have had an oxygen-protective function toward the volatile constituents of "Nukamiso-zuke" that are passed from "Nukadoko".

Acknowledgments. The authors express their thanks to Professor S. Arai of Tokyo University for his encouragement and advice in the experiments, and to $\mathrm{Mr}$. A. Shinohara of Takasago International Co. and S. Takahashi of Morinaga and Co. for helping with the analyses.

\section{References}

1) M. Imai, S. Hirano and M. Aiba, Nippon Nōgeikagaku Kaishi, 57, 1105 (1983).

2) M. Imai and $\mathrm{S}$. Goto, Nippon Nōgeikagaku Kaishi, 58, 545 (1984).

3). M. Imai, S. Hirano and M. Aiba, Nippon Nögeikagaku Kaishi, 57, 1113 (1983)

4) Y. Uda, H. Ikawa, O. Ishibashi and Y. Maeda, Nippon Shokuhin Kogyo Gakkaishi, 31, 371 (1984).

5) H. Itoh, K. Yoshida, T. Mizuno, M. Kudo, Y. Nikuni and T. Karki, Rept. Natl. Food Res. Inst., No. 45, 33 (1983).

6) K. Kasahara and K. Nishibori, J. Japanese Soc. of Food and Nutrition, 35, 71 (1982).

7) M. Kamiyama, S. Koizumi and T. Yanagida, Gekkan Shokuhin, 27, 71 (1983).

8) H. Ishii, Takasago Times, 77, 23 (1982).

9) R. Teranishi, "Flavor Research," Marcel Dekker Inc., New York, 1971, p. 55.

10) K. Imagawa, T. Yamanishi and M. Kojika, Nippon Nōgeikagaku Kaishi, 48, 561 (1974).

11) B. O. Julian, "Rice, Chemistry and Technology," 2nd 
ed., Am. Assoc. Cereal Chem. Inc., St. Paul, MN, 1985, p. 98.

12) A. D. Webb and J. L. Ingraham, "Advances in Applied Microbiology," Vol. 5, ed. by D. Perlman, Academic Press, New York, 1963, p. 317.

13) A. D. Webb and C. J. Muller, "Advances in Applied Microbiology," Vol, 15, ed. by D. Perlman, Academic Press, New York, 1972, p. 75.

14) M. Yoshioka and K. Endo, "Guidebook to Biochemistry," Nankohdo, Tokyo, 1969, p. 194.

15) S. Okui, M. Uchiyama and M. Mizugaki, J. Biochem. 54, 536 (1963).

16) M. E. Sharpe, T. F. Fryer and D. G. Smith, "Identification Methods for Microbiologists," Part A, ed. by B. M. Gibbs and F. A. Skinner, Academic Press, New York, 1966, p. 65.

17) R. G. Arnold, K. M. Shahani and B. K. Dwivedi, J. Dairy Sci., 58, 1127 (1975).

18) M. Kato, M. Kiuchi, T. Mori, H. Tabei and I Washimi, Nippon Shokuhin Kogyo Gakkaishi, 30, 99 (1983).
19) M. Fujimaki, T. Tsugita and T. Kurata, Agric. Biol. Chem., 41, 1721 (1977).

20) K. Yoshikawa and N. Hashimoto, Agric. Biol. Chem., 45, 2183 (1981).

21) T. Asai, T. Sakai and T. Yokotsuka, Nippon Nōgeikagaku Kaishi, 41, 1721 (1967).

22) I. L. Gatfield, "Biogeneration of Aromas," ACS Symposium Series, 317, ed. by T. H. Parliment and R. Croteu, American Chemical Society, Washington D. C., 1986, p. 317.

23) A. Kjaer, J. O. Madsen, Y. Maeda, Y. Ozawa and Y. Uda, Agric. Biol. Chem., 42, 1715 (1978).

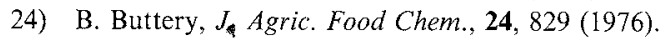

25) S. D. Bailey and M. L. Bazinet, J. Food Sci., 26, 163 (1961).

26) M. E. Ettlinger, G. P. Dateo, B. W. Harrison, T. J. Mabry and C. P. Thompson, Proc. Natl. Acad. Sci. U.S.A., 47, 1961 (1975).

27) J. A. Maga, CRC Crit. Rev. in Food Sci. Nutr., 10, 1 (1976). 